\title{
Salinicoccus qingdaonensis sp. nov., isolated from coastal seawater during a bloom of green algae
}

\author{
Zhe Qu, Zhao Li, Xiuming Zhang and Xiao-Hua Zhang \\ College of Marine Life Sciences, Ocean University of China, Qingdao, PR China
}

Correspondence

Xiao-Hua Zhang

xhzhang@ouc.edu.cn

\begin{abstract}
A novel Gram-stain-positive, white-pigmented, non-motile, non-sporulating, catalase- and oxidase-positive, strictly aerobic coccus, designated strain $Z X M 223^{\top}$, was isolated from a seawater sample collected from the coast of Qingdao, PR China, during a green algal bloom. It grew at $\mathrm{pH}$ 6.0-10.5 and 0-25.0\% (w/v) NaCl, with optimum growth at $\mathrm{pH} 8.5$ and $3.0 \%(\mathrm{w} / \mathrm{v})$ $\mathrm{NaCl}$. Growth occurred at $16-42{ }^{\circ} \mathrm{C}$ (optimum at $28{ }^{\circ} \mathrm{C}$ ). The major fatty acids were anteiso$\mathrm{C}_{15: 0}$ and iso- $\mathrm{C}_{15: 0}$. Menaquinone 6 (MK-6) was the major respiratory quinone. The polar lipids were phosphatidylglycerol, three unidentified phospholipids and two unknown glycolipids. The peptidoglycan type was L-Lys-Gly ${ }_{5-6}$. The genomic DNA G+C content was 43.5 mol\%.

Phylogenetic analysis of the $16 \mathrm{~S}$ rRNA gene sequence placed strain ZXM223 ${ }^{\top}$ within the genus Salinicoccus, with sequence similarity of 92.2-97.1\% between $Z X M 223^{\top}$ and the type strains of this genus. The closest relatives were Salinicoccus kunmingensis $\mathrm{YIM} \mathrm{Y15}^{\top}$, 'S. salitudinis' YIMC678 and S. alkaliphilus T8 ${ }^{\top}$. The DNA-DNA relatedness between strain $Z Z^{2} M 223^{\top}$ and $S$. kunmingensis CGMCC $1.6302^{\top}$ and 'S. salitudinis' CGMCC 1.6299 (=YIM-C678) was $37 \pm 3$ and $30 \pm 2 \%$, respectively. The phenotypic, chemotaxonomic and phylogenetic characteristics and low DNA-DNA relatedness support the proposal of a novel species of the genus Salinicoccus, Salinicoccus qingdaonensis sp. nov., with the type strain ZXM223 ${ }^{\top}$ (=LMG $24855^{\top}=$ CGMCC $1.8895^{\top}$ ).
\end{abstract}

Salinicoccus roseus was the first species of the genus Salinicoccus to be described, by Ventosa et al. (1990). The genus was defined as containing Gram-positive, moderately halophilic, non-motile, non-spore-forming, heterotrophic cocci. Microbes belonging to the genus Salinicoccus have generally been found in salty environments, such as salt mines, salted fish and fermented seafood. At the time of writing, the genus contained 12 species with validly published names: S. roseus (type species; Ventosa et al., 1990), S. hispanicus (Ventosa et al., 1992), S. alkaliphilus (Zhang et al., 2002), S. jeotgali (Aslam et al., 2007), S. kunmingensis (Chen et al., 2007), S. luteus (Zhang et al., 2007), S. salsiraiae (França et al., 2006), S. siamensis (Pakdeeto et al., 2007), S. halodurans (Wang et al., 2008), S. iranensis (Amoozegar et al., 2008), S. albus (Chen et al., 2009) and S. carnicancri (Jung et al., 2010); the name 'Salinicoccus salitudinis' (Chen et al., 2008) has not been validly published. In a study of the microbial diversity in a coastal area of Qingdao where massive green algal blooms occur, a halophilic strain, ZXM223 ${ }^{\mathrm{T}}$, was isolated from a seawater sample (collection location $36.047^{\circ} \mathrm{N} 120.341^{\circ} \mathrm{E}$ ). The phenotypic, chemotaxonomic and genotypic characteristics of strain $Z X M 223^{\mathrm{T}}$

The GenBank/EMBL/DDBJ accession number for the 16S rRNA gene sequence of strain $\mathrm{ZXM} 23^{\top}$ is FJ436724.

A supplementary alignment file, four supplementary figures and a supplementary table are available with the online version of this paper. indicated that it represented a novel species of the genus Salinicoccus.

The seawater sample was collected at a depth of $1 \mathrm{~m}$ during a bloom of the green alga Enteromorpha prolifera. The sample was serially diluted 10 -fold to $10^{-6}$ dilution with sterile seawater and spread on marine agar 2216 (MA; Difco) and then incubated at $28{ }^{\circ} \mathrm{C}$ for 7 days. A white colony was picked from a plate and, after isolation and purification, the isolate was named strain $\mathrm{ZXM} 223^{\mathrm{T}}$. The strain was maintained in $0.85 \%(\mathrm{w} / \mathrm{v}) \mathrm{NaCl}$ with $15 \%$ (v/v) glycerol at $-80{ }^{\circ} \mathrm{C}$. Unless otherwise specified, all studies were performed on MA at $28{ }^{\circ} \mathrm{C}$.

Cell morphology was observed by light microscopy (Olympus CX) and transmission electron microscopy (JEOL JEM-1200EX), with cells grown for $24 \mathrm{~h}$ at $28{ }^{\circ} \mathrm{C}$ on MA. Gram staining was carried out using the standard Gram reaction (Beveridge et al., 2007). Flagellation was examined by using both light microscopy after Leifson staining according to Beveridge et al. (2007) and transmission electron microscopy after negative staining with $1 \%(\mathrm{w} / \mathrm{v})$ phosphotungstic acid. Motility was detected by observation of growth on marine broth 2216 (MB; Difco) solidified with $0.3 \%$ agar. Anaerobic growth was determined after incubation in a glass vacuum desiccator on MA for 7 days at $28{ }^{\circ} \mathrm{C}$, with the reaction of $10 \mathrm{~g}$ gallic acid and $100 \mathrm{ml} 10 \% \mathrm{NaOH}$ used to consume oxygen. Capsule 
staining, endospore formation, catalase and oxidase activities and degradation of casein, gelatin, starch and Tweens 80 and 20 were studied by using standard protocols (Tindall et al., 2007), with suitably modified MA or MB. Poly- $\beta$-hydroxybutyrate (PHB) accumulation was observed with a fluorescence microscope (Olympus $\mathrm{BH} 2$ ) using Nile blue A as a fluorescent stain (Ostle \& Holt, 1982).

The $\mathrm{NaCl}$ tolerance range and optimum for growth were examined in $\mathrm{MB}$ in the absence of $\mathrm{NaCl}$ and $\mathrm{MB}$ containing $\mathrm{NaCl}$ at $0.5,1,1.5,2,3,6,9,12,15,20,23,24$ and $25 \%(\mathrm{w} / \mathrm{v})$ in a constant-temperature shaker. The growth temperature range was determined on MA plates at $0,4,10,16,25,28,32$, $37,40,42,45$ and $50{ }^{\circ} \mathrm{C}$. The $\mathrm{pH}$ tolerance range and optimum for growth were tested in $\mathrm{MB}$ prepared at $\mathrm{pH}$ 5.0-11.0 (at intervals of $0.5 \mathrm{pH}$ units) and $\mathrm{pH} 12.0$ by monitoring changes in $\mathrm{OD}_{600}$ with time at $28{ }^{\circ} \mathrm{C}$. These buffers were used in $\mathrm{pH}$ tolerance experiments: $\mathrm{pH}$ 5.0-5.5, $0.1 \mathrm{M}$ acetic acid/0.1 M sodium acetate; $\mathrm{pH}$ 6.0-8.0, 0.1 M $\mathrm{KH}_{2} \mathrm{PO}_{4} / 0.1 \mathrm{M} \mathrm{NaOH} ; \mathrm{pH} 8.5,0.05 \mathrm{M}$ Tris/HCl; pH 9.0$10.5, \quad 0.1 \mathrm{M} \mathrm{NaHCO} / / 0.1 \mathrm{M} \quad \mathrm{Na}_{2} \mathrm{CO}_{3} ; \mathrm{pH} 11.0,0.05 \mathrm{M}$ $\mathrm{Na}_{2} \mathrm{HPO}_{4} / 0.1 \mathrm{M} \mathrm{NaOH} ; \mathrm{pH} 12.0,0.2 \mathrm{M} \mathrm{KCl} / 0.2 \mathrm{M} \mathrm{NaOH}$. Susceptibility to antibiotics was determined by inoculating bacterial suspension on MA at $28{ }^{\circ} \mathrm{C}$ and applying antibiotics discs. Inhibition zones were measured after 2 days of incubation and interpreted according to the manufacturer's manual (Hangzhou Microbial Reagent Co.). Activities of constitutive enzymes, the fermentation/oxidation profile, acid production and substrate utilization as sole carbon and energy sources were determined twice by using API 20E, API 20NE, API 50CH (with API $50 \mathrm{CH} \mathrm{B/E} \mathrm{medium)} \mathrm{and} \mathrm{API}$ ZYM strips (bioMérieux) and Biolog GP and GN MicroPlates according to the manufacturer's instructions; sterile $3 \%$ (w/ v) $\mathrm{NaCl}$ was used to prepare the inocula. S. kunmingensis CGMCC $1.6302^{\mathrm{T}}$ and 'S. salitudinis' CGMCC 1.6299 (=YIMC678), obtained from the China General Microbiological Culture Collection Center, were used as reference strains.

For quantitative analysis of cellular fatty acid compositions, respiratory quinones and polar lipids, cell mass was harvested from $\mathrm{MB}$ after incubation at $28{ }^{\circ} \mathrm{C}$ for $48 \mathrm{~h}$, while strains were in their stationary phase, and freeze-dried. The analyses were then carried out by the Identification Service of the Deutsche Sammlung von Mikroorganismen und Zellkulturen GmbH (DSMZ, Braunschweig, Germany) and Dr Brian Tindall (DSMZ). Wet biomass was well suspended in 2-propanol/water $(1: 1, \mathrm{v} / \mathrm{v})$ for peptidoglycan structure analysis, which was also carried out by the Identification Service of the DSMZ. Peptidoglycan structure and amino acid composition were analysed according to Schleifer \& Kandler (1972) and MacKenzie (1987).

Genomic DNA was extracted and purified according to standard methods (Ausubel et al., 1995). The 16S rRNA gene was amplified by PCR with universal primers 27F (5'AGAGTTTGATCCTGGCTCAG-3') and 1492R (5'-GGTTACCTTGTTACGACTT-3'). PCR products were purified and sequenced by Shanghai Biosune (Shanghai, PR China) with an Applied Biosystems automatic sequencer (ABI
3730). The $16 \mathrm{~S}$ rRNA gene sequence of strain $\mathrm{ZXM}_{2} 23^{\mathrm{T}}$ was compared and aligned with available sequences in the GenBank database by BLAST, and was also compared with those in the EzTaxon public database (http://www.eztaxon. org/; Chun et al., 2007). Phylogenetic analysis was performed using the MEGA version 4.0 software package (Tamura et al., 2007) after multiple alignment of sequence data by ClUSTAL w (Thompson et al., 1997). The sequence alignment is available as Supplementary File S1 (available in IJSEM Online). Phylogenetic trees were established with the neighbour-joining, maximum-parsimony and minimumevolution DNA distance programs in the MEGA package (Tamura et al., 2007). Bootstrap values were determined based on 1000 replications.

The DNA G $+\mathrm{C}$ content was determined by the method of Mesbah et al. (1989) using reversed-phase HPLC. DNADNA hybridization experiments were performed with genomic DNA from strain $\mathrm{ZXM} 223^{\mathrm{T}}$, S. kunmingensis CGMCC $1.6302^{\mathrm{T}}$ and 'S. salitudinis' CGMCC 1.6299 using a method described previously (Liu \& Shao, 2005). The hybridization temperature was $42{ }^{\circ} \mathrm{C}$ and the formamide concentration was $50 \%$. The DIG High Prime DNA Labelling and Detection Starter kit II (Roche) was used in this study.

Colonies of strain $\mathrm{ZXM}_{22} 3^{\mathrm{T}}$ were circular, convex, whitepigmented and 1-2 $\mathrm{mm}$ in diameter after incubation for 3 days at $28{ }^{\circ} \mathrm{C}$ on MA. No diffusible pigments were produced. Cells of strain ZXM $223^{\mathrm{T}}$ were Gram-stain-positive cocci, approximately $0.4-0.6 \mu \mathrm{m}$ in diameter (Supplementary Fig. S1), occurring singly and in pairs, tetrads or clumps, and were strictly aerobic, non-motile, non-sporulating, negative for $\mathrm{PHB}$ accumulation and positive for presence of a capsule, with no flagella present. Strain $\mathrm{ZXM} 223^{\mathrm{T}}$ grew at $16-42{ }^{\circ} \mathrm{C}$ and grew over wide ranges of $\mathrm{NaCl}$ concentration $(0-25.0 \%, \mathrm{w} / \mathrm{v})$ and $\mathrm{pH}(\mathrm{pH} 6.0-10.5)$. Optimal growth was observed at $28{ }^{\circ} \mathrm{C}, 3.0 \%(\mathrm{w} / \mathrm{v}) \mathrm{NaCl}$ and $\mathrm{pH} 8.5$. The major fatty acids were anteiso- $\mathrm{C}_{15: 0}(33.7 \%)$, iso- $\mathrm{C}_{15: 0}$ $(19.6 \%)$, anteiso- $\mathrm{C}_{17: 0}(9.2 \%)$, iso- $\mathrm{C}_{17: 0}(9.0 \%)$ and $\mathrm{C}_{16: 0}$ $(8.7 \%)$. The fatty acid profiles of strain $\mathrm{ZXM} 223^{\mathrm{T}}$ and $S$. kunmingensis CGMCC $1.6302^{\mathrm{T}}$ are given in Supplementary Table S1. Strain ZXM $223^{\mathrm{T}}$ had menaquinone 6 (MK-6) $(100 \%)$ as its respiratory quinone. Phosphatidylglycerol, three unidentified phospholipids and two unknown glycolipids were the major polar lipid components of strain ZXM $223^{\mathrm{T}}$ (Supplementary Fig. S2), which differed from the major polar lipids of the few other species in the genus for which polar lipid analysis has been reported (Table 1). The chemotaxonomic features are in general agreement with those of other members of Salinicoccus. Other phenotypic characteristics are listed in Table 1 and the species description.

The almost-complete 16S rRNA gene sequence (1408 bp) of strain $\mathrm{ZXM} 223^{\mathrm{T}}$ was determined. Sequence similarity calculations indicated that the closest relatives of strain $\mathrm{ZXM}_{22} 3^{\mathrm{T}}$ were S. kunmingensis YIM Y15 ${ }^{\mathrm{T}}(97.1 \%$ sequence similarity), 'S. salitudinis' YIM-C678 (96.8\%) 
Table 1. Differentiating characteristics of strain $Z X M 223^{\top}$ and its closest phylogenetic relatives

Strains: 1, strain ZXM223 ${ }^{\mathrm{T}}$ (data from this study); 2, S. kunmingensis YIM Y15 ${ }^{\mathrm{T}}$ (unless indicated, data from Chen et al., 2007); 3, 'S. salitudinis' YIM-C678 (Chen et al., 2008); 4, S. alkaliphilus $\mathrm{T}^{\mathrm{T}}$ (Zhang et al., 2002); 5, S. jeotgali S2R53-5 ${ }^{\mathrm{T}}$ (Aslam et al., 2007); 6, S. siamensis PN1-2 ${ }^{\mathrm{T}}$ (Pakdeeto et al., 2007); 7, S. roseus DSM 5351 ${ }^{\mathrm{T}}$ (Ventosa et al., 1990); 8, S. salsiraiae RH1 ${ }^{\mathrm{T}}$ (França et al., 2006); 9, S. hispanicus DSM 5352 ${ }^{\mathrm{T}}$ (Ventosa et al., 1992); 10, S. carnicancri $\mathrm{Crm}^{\mathrm{T}}$ (Jung et al., 2010); 11, S. albus YIM-Y21 ${ }^{\mathrm{T}}$ (Chen et al., 2009); 12, S. luteus YIM $70202^{\mathrm{T}}$ (Zhang et al., 2007). +, Positive; -, negative; tr, trace; ND, no data available. All strains are positive for Gram staining and catalase and oxidase activities and negative for spore formation and motility.

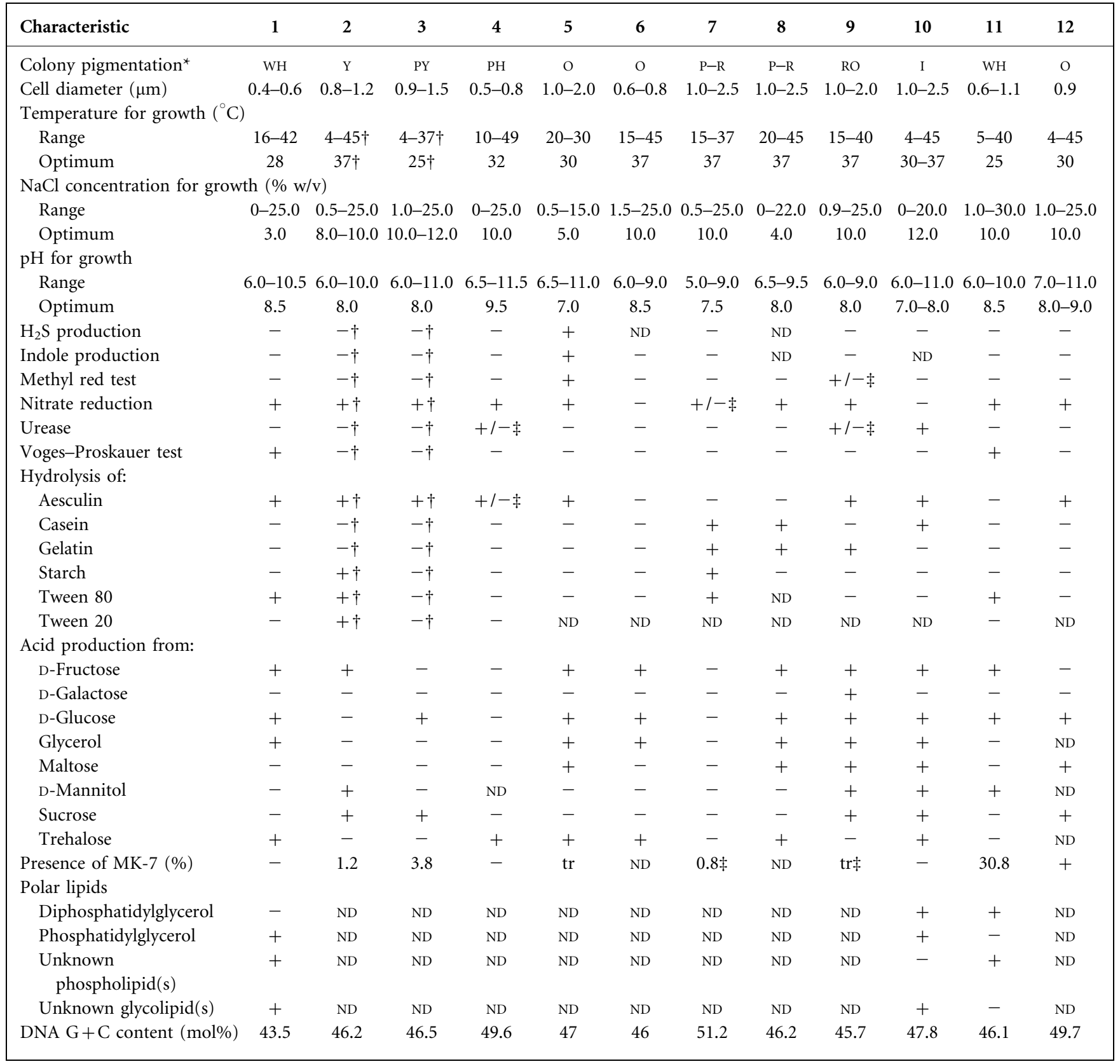

${ }^{\star}$ I, Ivory; O, orange; P, pink; PH, pinkish; PY, pale yellow; R, red; RO, reddish orange; WH, white; Y, yellow.

$\dagger$ Confirmed in this study in parallel tests for S. kunmingensis CGMCC $1.6302^{\mathrm{T}}$ and 'S. salitudinis' CGMCC 1.6299 under identical conditions. \$Data from Chen et al. (2007, 2008).

and S. alkaliphilus $\mathrm{T}^{\mathrm{T}}(96.2 \%)$. Phylogenetic analysis indicated that strain $\mathrm{ZXM} 223^{\mathrm{T}}$ was closely related to the type strains of the genus Salinicoccus (Ventosa et al., 1990), and these strains formed a distinct clade in the phylogenetic tree (Fig. 1) with significant bootstrap support $(99 \%)$, in which strain ZXM223 ${ }^{\mathrm{T}}$, S. kunmingensis YIM 
$\mathrm{Y} 15^{\mathrm{T}}$ and ' $S$. salitudinis' YIM-C678 formed a distinct subclade (Fig. 1). Trees reconstructed by the maximumparsimony and minimum-evolution method are shown in Supplementary Figs S3 and S4. The results of our phylogenetic analysis revealed that strain $Z X M 223^{\mathrm{T}}$ could represent a previously unknown species of the genus Salinicoccus.

The DNA G $+C$ content of strain $\mathrm{ZXM}_{22} 3^{\mathrm{T}}$ was $43.5 \mathrm{~mol} \%$. DNA-DNA hybridization experiments showed low DNADNA relatedness between strain $\mathrm{ZXM}_{2} 23^{\mathrm{T}}$ and S. kunmingensis CGMCC $1.6302^{\mathrm{T}}(37 \pm 3 \%)$ and between strain $\mathrm{ZXM}_{223}{ }^{\mathrm{T}}$ and ' $S$. salitudinis' CGMCC $1.6299(30 \pm 2 \%)$, demonstrating their affiliation to separate species in accordance with the cut-off value of $70 \%$ recognized by Wayne et al. (1987) for discrimination of bacterial species.

The phylogenetic data and its morphological, biochemical and chemotaxonomic characteristics support the conclusion that strain $\mathrm{ZXM} 223^{\mathrm{T}}$ should be assigned to the genus Salinicoccus. However, the white colony pigmentation, comparatively small colony diameter, low optimum salinity for growth (3\%) and positive Voges-Proskauer test reaction, as well as the ability to hydrolyse Tween 80 and produce acid from glycerol and trehalose, together with the low 16S rRNA gene sequence similarities with species of the genus Salinicoccus and the low level of DNADNA relatedness, clearly distinguished strain $Z X M 223^{\mathrm{T}}$ from other members of the genus. On the basis of its distinct phenotypic and genetic properties, we conclude that strain ZXM $223^{\mathrm{T}}$ represents a novel species of the genus Salinicoccus, for which the name Salinicoccus qingdaonensis sp. nov. is proposed.

\section{Description of Salinicoccus qingdaonensis sp. nov.}

Salinicoccus qingdaonensis (qing.dao.nen'sis. N.L. masc. adj. qingdaonensis pertaining to Qingdao, a city in the coastal region of east China, near the sampling site from which the type strain was isolated).

Cells are strictly aerobic, non-motile, non-sporulating cocci (0.4-0.6 $\mu \mathrm{m}$ in diameter) that occur singly or in pairs, tetrads or clumps. Gram-stain-positive, with a capsule. Catalase- and oxidase-positive and negative for gelatinase and $\mathrm{PHB}$ accumulation. Colonies are white, circular, smooth and convex, 1-2 $\mathrm{mm}$ in diameter after 3 days of incubation at $28{ }^{\circ} \mathrm{C}$ on $\mathrm{MA}$, with no diffusible pigment production. Moderately halophilic, with growth at 0-25.0\% (w/v) NaCl. Growth occurs at $\mathrm{pH} 6.0-10.5$ and at $16-42{ }^{\circ} \mathrm{C}$. Optimum growth at $3.0 \%(\mathrm{w} / \mathrm{v}) \mathrm{NaCl}, \mathrm{pH} 8.5$ and $28{ }^{\circ} \mathrm{C}$. Nitrate is reduced to nitrite. $\mathrm{H}_{2} \mathrm{~S}$ and indole production and methyl red test are negative, but Voges-Proskauer test is positive. Aesculin and Tween 80 are hydrolysed, but casein, chitin, gelatin, starch and Tween 20 are not. Constitutive enzymes expressed by the type strain are $\alpha$-Phe-Pro arylamidase, leucine aminopeptidase, L-pyrrolidonyl arylamidase and naphthol-AS-BI-phosphoamidase; acid phosphatase, alkaline phosphatase, arginine dihydrolase, $\alpha$ chymotrypsin, $\alpha$-fucosidase, $\alpha$-galactosidase, $\alpha$-glucosidase, $\alpha$-mannosidase, $\beta$-alanine arylamidase, $\beta$-galactosidase, $\beta$ glucuronidase, $\beta$-glucosidase, $\beta$-xylosidase, $\gamma$-glutamyl transferase, cystine aminopeptidase, arginine decarboxylase, esterase (C4), esterase lipase (C8), Glu-Gly-Arg arylamidase, glutamyl arylamidase, glycine arylamidase, L-proline arylamidase, lipase (C14), lysine decarboxylase, $N$-acetyl- $\beta$ galactosaminidase, $N$-acetyl- $\beta$-glucosaminidase, ornithine decarboxylase, trypsin, tyrosine arylamidase, tryptophan deaminase, urease and valine aminopeptidase are not expressed. Acid is produced from D-fructose, D-glucose, trehalose, glycerol, $\mathrm{N}$-acetylglucosamine and potassium 5ketogluconate. In Biolog GP2 and GN2 plates, the following substrates are used as sole carbon and energy sources: Dfructose, $\alpha$-D-glucose, D-mannose, D-psicose, trehalose, acetic acid, $\alpha$-hydroxybutyric acid, L-lactic acid, L-malic acid, succinic acid monomethyl ester, propionic acid, pyruvic acid, succinic acid, L-alaninamide, L-alanine, L-alanyl glycine, L-glutamic acid, glycyl L-glutamic acid, Lpyroglutamic acid, L-serine, glycerol, thymidine, uridine, $N$ acetyl-D-glucosamine, monomethyl succinate, acetic acid, formic acid, $\alpha$-ketobutyric acid, bromosuccinic acid, succinamic acid, L-asparagine, L-aspartic acid, L-histidine, hydroxy-L-proline, L-ornithine, L-proline, L-threonine and urocanic acid. Cells are susceptible to the following ( $\mu$ g per disc, unless indicated): midecamycin (30), ofloxacin (5),

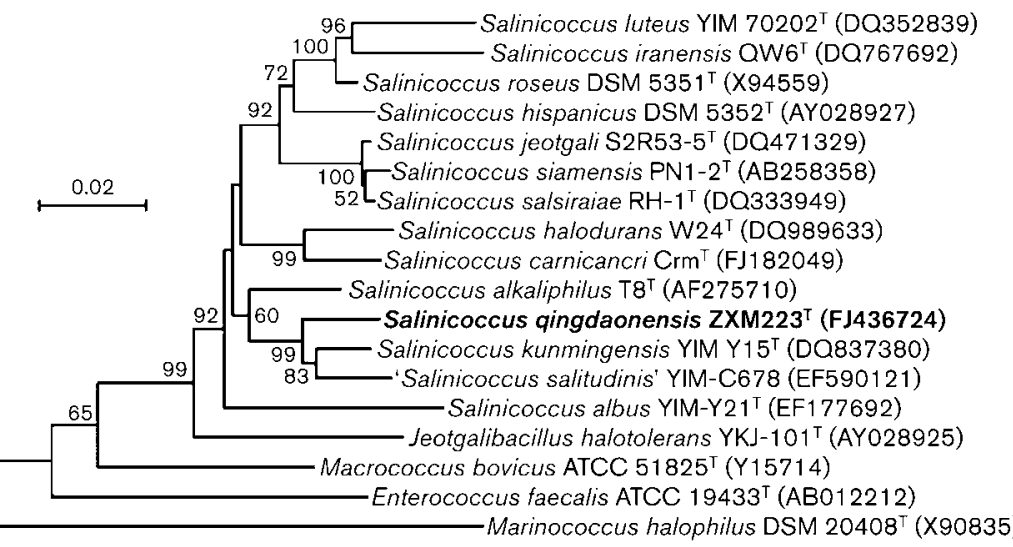

Fig. 1. Phylogenetic tree based on $16 \mathrm{~S}$ rRNA gene sequence analysis and reconstructed using the neighbour-joining method showing the phylogenetic positions of strain $Z X M 223^{\top}$ and related taxa. Branches were also recovered with the maximum-parsimony and minimum-evolution method (see Supplementary Figs S3 and S4). Numbers at nodes indicate bootstrap values $(>50 \%)$ based on neighbour-joining analyses of 1000 resampled datasets. Bar, 2 substitutions per 100 nucleotide positions. 
ciprofloxacin (5), vancomycin (30), furazolidone (300), chloromycetin (30), clindamycin (2), cefobid (30), amikacin (30), vibramycin (30), minocycline (30), erythromycin (15), penicillin (10), oxacillin (1), ampicillin (10), carbenicillin (100), piperacillin (100), cephalothin IV (30), cephalothin V (30), cephalothin VI (30) and rocephin (30), but resistant to norfloxacin (10), polymyxin B (100 U), compound sulfamethoxazole (75), gentamicin (10), kanamycin (30), neomycin (10), tetracycline (30) and fortum (30). The major fatty acids are anteiso- $\mathrm{C}_{15: 0}$, iso- $\mathrm{C}_{15: 0}$, anteiso- $\mathrm{C}_{17: 0}$, iso$\mathrm{C}_{17: 0}$ and $\mathrm{C}_{16: 0}$. MK-6 is the predominant respiratory quinone. The polar lipids consist of phosphatidylglycerol, three unidentified phospholipids and two unknown glycolipids. The cell-wall peptidoglycan type is L-Lys-Gly ${ }_{5-6}$. The DNA $G+C$ content of the type strain is $43.5 \mathrm{~mol} \%$.

The type strain, ZXM $223^{\mathrm{T}}\left(=\mathrm{LMG} 24855^{\mathrm{T}}=\mathrm{CGMCC}\right.$ $1.8895^{\mathrm{T}}$ ), was isolated from a seawater sample collected from coastal seawater of Qingdao, east China, during a bloom of the green alga Enteromorpha prolifera.

\section{Acknowledgements}

This work was supported by the National High Technology R\&D Program of China (grant no. 2007AA09Z434), and the National Natural Science Foundation of China (grant no. 40876067).

\section{References}

Amoozegar, M. A., Schumann, P., Hajighasemi, M., Ashengroph, M. \& Razavi, M. R. (2008). Salinicoccus iranensis sp. nov., a novel moderate halophile. Int J Syst Evol Microbiol 58, 178-183.

Aslam, Z., Lim, J. H., Im, W.-T., Yasir, M., Chung, Y. R. \& Lee, S.-T. (2007). Salinicoccus jeotgali sp. nov., isolated from jeotgal, a traditional Korean fermented seafood. Int J Syst Evol Microbiol 57, 633-638.

Ausubel, F. M., Brent, R., Kingston, R. E., Moore, D. D., Seidman, J. G., Smith, J. A. \& Struhl, K. (editors) (1995). Short Protocols in Molecular Biology: a Compendium of Methods from Current Protocols in Molecular Biology, 3rd edn, pp. 211-214. New York: Wiley.

Beveridge, T. J., Lawrence, J. R. \& Murray, R. G. E. (2007). Sampling and staining for light microscopy. In Methods for General and Molecular Microbiology, pp. 19-33. Edited by C. A. Reddy, T. J. Beveridge, J. A. Breznak, G. Marzluf, T. M. Schmidt \& L. R. Snyder. Washington, DC: American Society for Microbiology.

Chen, Y.-G., Cui, X.-L., Pukall, R., Li, H.-M., Yang, Y.-L., Xu, L.-H., Wen, M.-L., Peng, Q. \& Jiang, C.-L. (2007). Salinicoccus kunmingensis sp. nov., a moderately halophilic bacterium isolated from a salt mine in Yunnan, south-west China. Int J Syst Evol Microbiol 57, 2327-2332.

Chen, Y.-G., Cui, X.-L., Li, W.-J., Xu, L.-H., Wen, M.-L., Peng, Q. \& Jiang, C.-L. (2008). Salinicoccus salitudinis sp. nov., a new moderately halophilic bacterium isolated from a saline soil sample. Extremophiles 12, 197-203.

Chen, Y.-G., Cui, X.-L., Wang, Y.-X., Zhang, Y.-O., Li, Q.-Y., Liu, Z.-X., Wen, M.-L., Peng, Q. \& Li, W.-J. (2009). Salinicoccus albus sp. nov., a halophilic bacterium from a salt mine. Int J Syst Evol Microbiol 59, 874-879.

Chun, J., Lee, J.-H., Jung, Y., Kim, M., Kim, S., Kim, B. K. \& Lim, Y. W. (2007). EzTaxon: a web-based tool for the identification of prokaryotes based on $16 \mathrm{~S}$ ribosomal RNA gene sequences. Int J Syst Evol Microbiol 57, 2259-2261.

França, L., Rainey, F. A., Nobre, M. F. \& da Costa, M. S. (2006). Salinicoccus salsiraiae sp. nov.: a new moderately halophilic grampositive bacterium isolated from salted skate. Extremophiles 10, 531536.

Jung, M. J., Kim, M. S., Roh, S. W., Shin, K. S. \& Bae, J. W. (2010). Salinicoccus carnicancri sp. nov., a halophilic bacterium isolated from a Korean fermented seafood. Int J Syst Evol Microbiol 60, 653-658.

Liu, C. \& Shao, Z. (2005). Alcanivorax dieselolei sp. nov., a novel alkane-degrading bacterium isolated from sea water and deep-sea sediment. Int J Syst Evol Microbiol 55, 1181-1186.

MacKenzie, S. L. (1987). Gas chromatographic analysis of amino acids as the $N$-heptafluorobutyryl isobutyl esters. J Assoc Off Anal Chem 70, 151-160.

Mesbah, M., Premachandran, U. \& Whitman, W. B. (1989). Precise measurement of the $\mathrm{G}+\mathrm{C}$ content of deoxyribonucleic acid by highperformance liquid chromatography. Int J Syst Bacteriol 39, 159-167. Ostle, A. G. \& Holt, J. G. (1982). Nile blue A as a fluorescent stain for poly- $\beta$-hydroxybutyrate. Appl Environ Microbiol 44, 238-241.

Pakdeeto, A., Tanasupawat, S., Thawai, C., Moonmangmee, S., Kudo, T. \& Itoh, T. (2007). Salinicoccus siamensis sp. nov., isolated from fermented shrimp paste in Thailand. Int J Syst Evol Microbiol 57, 2004-2008.

Schleifer, K. H. \& Kandler, O. (1972). Peptidoglycan types of bacterial cell walls and their taxonomic implications. Bacteriol Rev 36, 407-477.

Tamura, K., Dudley, J., Nei, M. \& Kumar, S. (2007). MEGA4: molecular evolutionary genetics analysis (MEGA) software version 4.0. Mol Biol Evol 24, 1596-1599.

Thompson, J. D., Gibson, T. J., Plewniak, F., Jeanmougin, F. \& Higgins, D. G. (1997). The CLUSTAL_X windows interface: flexible strategies for multiple sequence alignment aided by quality analysis tools. Nucleic Acids Res 25, 4876-4882.

Tindall, B. J., Sikorski, J., Smibert, R. M. \& Krieg, N. R. (2007). Phenotypic characterization and the principles of comparative systematics. In Methods for General and Molecular Microbiology, pp. 330-393. Edited by C. A. Reddy, T. J. Beveridge, J. A. Breznak, G. Marzluf, T. M. Schmidt \& L. R. Snyder. Washington, DC: American Society for Microbiology.

Ventosa, A., Marquez, M. C., Ruiz-Berraquero, F \& Kocur, M. (1990). Salinicoccus roseus gen. nov. sp. nov., a new moderately halophilic gram-positive coccus. Syst Appl Microbiol 13, 29-33.

Ventosa, A., Marquez, M. C., Weiss, N. \& Tindall, B. J. (1992). Transfer of Marinococcus hispanicus to the genus Salinicoccus as Salinicoccus hispanicus comb. nov. Syst Appl Microbiol 15, 530-534.

Wang, X., Xue, Y., Yuan, S., Zhou, C. \& Ma, Y. (2008). Salinicoccus halodurans sp. nov., a moderate halophile from saline soil in China. Int J Syst Evol Microbiol 58, 1537-1541.

Wayne, L. G., Brenner, D. J., Colwell, R. R., Grimont, P. A. D., Kandler, O., Krichevsky, M. I., Moore, L. H., Moore, W. E. C., Murray, R. G. E. \& other authors (1987). Report of the ad hoc committee on reconciliation of approaches to bacterial systematics. Int J Syst Bacteriol 37, 463464.

Zhang, W., Xue, Y., Ma, Y., Zhou, P., Ventosa, A. \& Grant, W. D. (2002). Salinicoccus alkaliphilus sp. nov., a novel alkaliphile and moderate halophile from Baer Soda Lake in Inner Mongolia Autonomous Region, China. Int J Syst Evol Microbiol 52, 789-793.

Zhang, Y.-Q., Yu, L.-Y., Liu, H.-Y., Zhang, Y.-Q., Xu, L.-H. \& Li, W.-J. (2007). Salinicoccus luteus sp. nov., isolated from a desert soil. Int $J$ Syst Evol Microbiol 57, 1901-1905. 